\title{
Study of the bank filtered groundwater system of the Sava River at Zagreb (Croatia) using isotope analyses
}

\author{
Nada Horvatinčić, Jadranka Barešić, \\ Ines Krajcar Bronić \\ Rudjer Boškovic Institute, Zagreb
}

Bogomil Obelić

Rudjer Boškovic Institute, Zagreb

\author{
Krisztina Kármán, István Fórizs \\ Institute for Geochemical Research, \\ Hungarian Academy of Sciences, Budapest
}

Radioactive isotope tritium $\left({ }^{3} \mathrm{H}\right)$ and stable isotopes of hydrogen $\left({ }^{2} \mathrm{H} /{ }^{1} \mathrm{H}\right)$ and oxygen $\left({ }^{18} \mathrm{O} /{ }^{16} \mathrm{O}\right)$ were measured during 2010 in the Sava River, precipitation and groundwater at 3 monitoring wells and 1 production well of the Petruševec aquifer, close to the Sava River in the Zagreb area. Significant increase of ${ }^{3} \mathrm{H}$ activity in the Sava River was observed in June, $(200 \pm 20) \mathrm{TU}$, and in groundwater of all wells with damped response (maximum $60 \mathrm{TU}$ ) and with delay of 3-5 months related to the Sava River. This increase was explained by release of tritiated water from the Krško Nuclear Power Plant, $30 \mathrm{~km}$ upstream from Zagreb in the beginning of June 2010. Stable isotope analyses showed similar range of $\delta^{2} \mathrm{H}$ and $\delta^{18} \mathrm{O}$ values for the Sava River and groundwater samples with higher variations in surface water. Differences in monthly variations of $\delta^{18} \mathrm{O}$ values between particular monitoring wells, together with ${ }^{3} \mathrm{H}$ values, indicated different infiltration times of surface water of the Sava River to different wells of the Petruševec aquifer.

Key words: tritium ${ }^{3} \mathrm{H}$, stable isotopes ${ }^{2} \mathrm{H}$ and ${ }^{18} \mathrm{O}$, Sava River, Petruševec aquifer

\section{Introduction}

Measurements of radioactive isotope tritium $\left({ }^{3} \mathrm{H}\right)$ and stable isotopes of hydrogen $\left({ }^{2} \mathrm{H} /{ }^{1} \mathrm{H}\right)$ and oxygen $\left({ }^{18} \mathrm{O} /{ }^{16} \mathrm{O}\right)$ can give useful information in hydrogeological studies of (i) mixing of surface and groundwaters, (ii) water circulation in nature, especially in karst areas, and (iii) mean residence time of water in aquifers. Increased ${ }^{3} \mathrm{H}$ activities in natural waters may indicate some contamination, such as global contamination of atmosphere with ${ }^{3} \mathrm{H}$ due to

Addresses: N. Horvatinčić, J. Barešic, I. Krajcar Bronić, B. Obelić: Bijenička 54, 10000 Zagreb,

Croatia, e-mail: nada.horvatincic@ibr.hr

K. Kármán, I. Fórizs: H-1112 Budapest, Budaörsi út 45, Hungary

Received: May 11, 2011; accepted: May 6, 2011 
atmospheric thermonuclear bomb tests (Rozanski et al. 1991), or local contamination due to release of tritiated waters from various nuclear facilities.

${ }^{3} \mathrm{H}$ and stable isotope ${ }^{2} \mathrm{H} /{ }^{1} \mathrm{H}$ and ${ }^{18} \mathrm{O} /{ }^{16} \mathrm{O}$ ratios in monthly precipitation of the Zagreb area have been measured since 1979, and the results have been included into the GNIP (Global Network of Isotopes in Precipitation) database (IAEA/WMO, 2011) of the International Atomic Energy Agency (IAEA). The investigation of the Petruševec aquifer in the Zagreb area is included in the Regional IAEA Project RER/8/016 Using Environmental Isotopes for Evaluation of Streamwater/Groundwater Interactions in Selected Aquifers in the Danube Basin with the aim to determine the influence of surface stream of the Sava River on the groundwater of aquifer used for water exploitation.

\section{Sampling and measurement}

${ }^{3} \mathrm{H},{ }^{2} \mathrm{H} /{ }^{1} \mathrm{H}$ and ${ }^{18} \mathrm{O} /{ }^{16} \mathrm{O}$ were measured during 2010 in the Sava River, precipitation and groundwater at 3 monitoring wells (piezometers) and 1 production well of the Petruševec aquifer, close to the Sava River in Zagreb area. Groundwater samples were collected monthly and the Sava River weekly for stable isotopes. Details of the sampling sites are given in Table 1.

Measurements of ${ }^{3} \mathrm{H}$ activities in waters were performed by the liquid scintillation counter Quantulus 1220 (Barešič et al. 2011). All samples were electrolytically enriched prior to LSC measurements. The system for electrolytic enrichment consists of 20 cells, the initial volume of water is $500 \mathrm{~mL}$ and the final

Table 1

Sampling data

\begin{tabular}{lccl}
\hline \multicolumn{1}{c}{ Location } & $\begin{array}{c}\text { Distance from the } \\
\text { Save R. }(\mathbf{m})\end{array}$ & $\begin{array}{c}\text { Depth } \\
(\mathbf{m})\end{array}$ & $\begin{array}{c}\text { Analysis and sampling } \\
\text { frequency }\end{array}$ \\
\hline $\begin{array}{l}\text { Sava R., Zagreb, below the bridge } \\
\text { "Domovinkki most" }\end{array}$ & & & $\begin{array}{l}{ }^{3} \mathrm{H}-\text { monthly } \\
{ }^{2} \mathrm{H} /{ }^{1} \mathrm{H},{ }^{18} \mathrm{O} /{ }^{16} \mathrm{O}-\text { weekly }\end{array}$ \\
\hline $\begin{array}{l}\text { Precipitation, Zagreb } \\
\text { Meteorological station Gric }\end{array}$ & & & $\begin{array}{l}{ }^{3} \mathrm{H},{ }^{2} \mathrm{H} /{ }^{1} \mathrm{H},{ }^{18} \mathrm{O} /{ }^{16} \mathrm{O}-\text { monthly } \\
\text { integrated sample }\end{array}$ \\
\hline Well B-5A, Petruševec & 400 & 38.0 & ${ }^{3} \mathrm{H},{ }^{2} \mathrm{H} /{ }^{1} \mathrm{H},{ }^{18} \mathrm{O} /{ }^{16} \mathrm{O}-$ monthly \\
\hline Piezometer PP-23/5, Petruševec & 200 & 16.4 & ${ }^{3} \mathrm{H},{ }^{2} \mathrm{H} /{ }^{1} \mathrm{H},{ }^{18} \mathrm{O} /{ }^{16} \mathrm{O}-$ monthly \\
Piezometer PP-18/30, Petruševec & 500 & 32.0 & ${ }^{3} \mathrm{H},{ }^{2} \mathrm{H} /{ }^{1} \mathrm{H},{ }^{18} \mathrm{O} /{ }^{16} \mathrm{O}-$ monthly \\
\hline Piezometer PP-19, Petruševec & 500 & 41.6 & ${ }^{3} \mathrm{H},{ }^{2} \mathrm{H} /{ }^{1} \mathrm{H},{ }^{18} \mathrm{O} /{ }^{16} \mathrm{O}-$ monthly \\
\hline
\end{tabular}

volume is $19 \pm 1 \mathrm{~mL}$ resulting in the mean enrichment factor of $22.5 \pm 0.5$. The limit of detection is $0.3 \mathrm{TU}$ (TU - Tritium unit, $1 \mathrm{TU}=0.118 \mathrm{~Bq} / \mathrm{L}$ ).

The oxygen and hydrogen isotopic composition was analysed with a Liquid Water Isotope Analyser (LWIA-24d) by Los Gatos Research. The initial water sample volumes of $1 \mathrm{ml}$ have been analyzed twice, with $<10$ microliter injected 
into the instrument during each measurement. The uncertainty of the measurements is $\pm 0.2 \%$ o for $\delta^{18} \mathrm{O}$ and $\pm 0.6 \%$ or for $\delta^{2} \mathrm{H}$.

\section{Results and discussion}

${ }^{3} \mathrm{H}$ activity (Fig. 1) in precipitation showed slight seasonal fluctuation between $4 \mathrm{TU}$ and $14 \mathrm{TU}$, with higher values in summer. ${ }^{3} \mathrm{H}$ activity of the Sava River and groundwater of the Petruševec aquifer followed ${ }^{3} \mathrm{H}$ of precipitation till May 2010. Significant increase of ${ }^{3} \mathrm{H}$ activity in the Sava River, $(200 \pm 20) \mathrm{TU}$, was observed in June and in the next month it fell down to 6 TU. This increase was explained by release of tritiated water from the Krško Nuclear Power Plant, $30 \mathrm{~km}$ upstream from Zagreb in the beginning of June 2010 (Stepišnik et al. 2011). Increase of ${ }^{3} \mathrm{H}$ was also observed in groundwater of all monitoring wells and the production well with damped response and a delay of several months in relation to the Sava River. The maximum ${ }^{3} \mathrm{H}$ activity ( $\left.\sim 60 \mathrm{TU}\right)$ was observed in monitoring wells PP23/5 and PP-18/30 with the delay of 3 and 5 months, respectively. The second peak activity in piezometer PP-23/5 in November could be resulted by the extremely high level of Sava River in September 2010. In the deepest groundwater of well B-5A and in piezometer PP-19 (Table 1) the rate of increase of ${ }^{3} \mathrm{H}$ activity was slower and the maximum value was lower (30 TU).

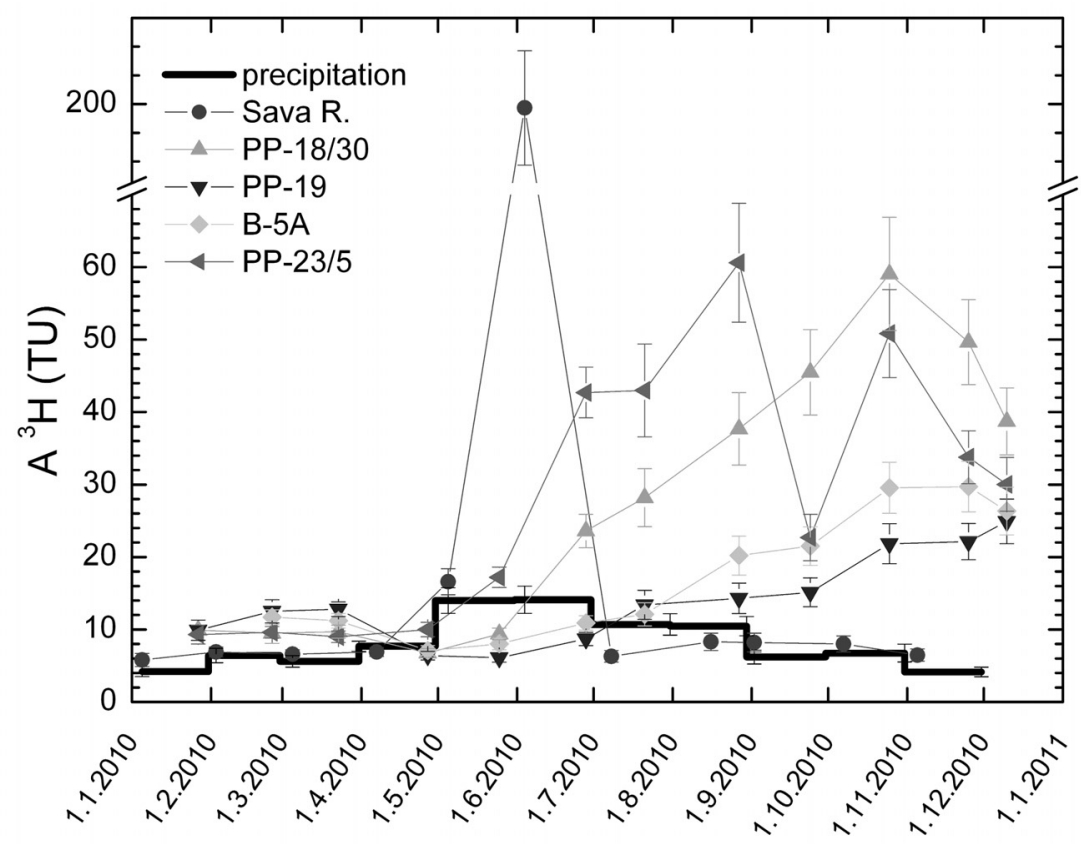

Fig. 1

${ }^{3} \mathrm{H}$ activities in monthly precipitation and in the Sava River and groundwaters from the Petruševec aquifer (piezometers PP-23/5, PP-18/30, PP-19, well B-5A) during 2010 
Stable isotope analyses of precipitation (Fig. 2) showed seasonal variations of $\delta^{2} \mathrm{H}$ and $\delta^{18} \mathrm{O}$ values typical for continental precipitation. The relation of $\delta^{2} \mathrm{H}$ vs. $\delta^{18} \mathrm{O}$ for Zagreb precipitation in 2010 (Fig. 3) is $\delta^{2} \mathrm{H}=(7.7 \pm 0.3) \delta^{18} \mathrm{O}+(6.1 \pm$ $3.2), \mathrm{n}=12, \mathrm{R}=0.992$, and it is in agreement with the long-term (1980-2003) Local Meteoric Water Line (LMWL) for Zagreb: $\delta^{2} \mathrm{H}=(7.8 \pm 0.1) \delta^{18} \mathrm{O}+(5.7 \pm$ $0.8), \mathrm{n}=271, \mathrm{R}=0.98$ (Vreča et al. 2006).

The range of $\delta^{2} \mathrm{H}$ and $\delta^{18} \mathrm{O}$ values (Table 2) for the Sava River and groundwater samples was similar with higher variations in surface water. The regression line

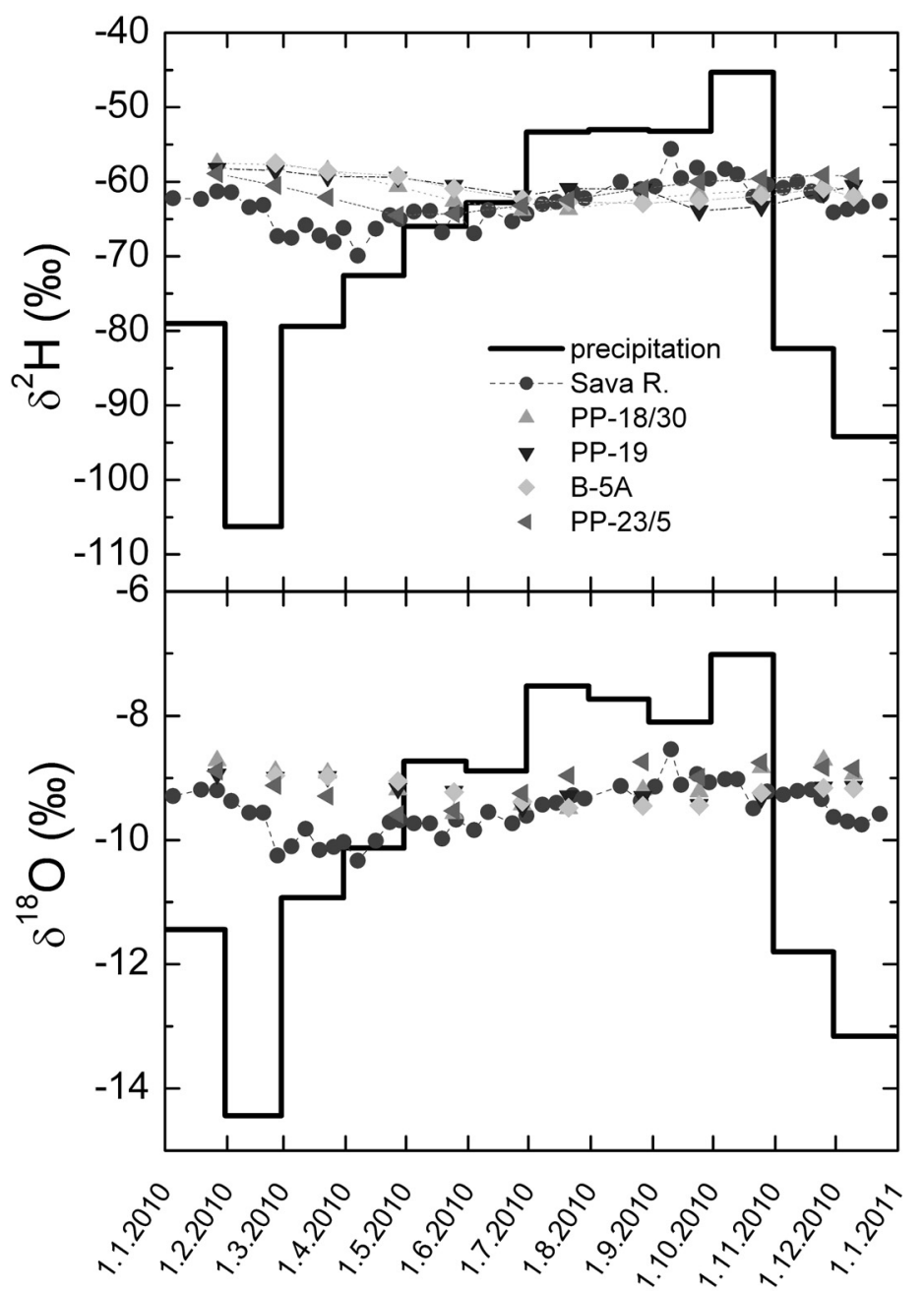

Fig. 2

$\delta^{2} \mathrm{H}$ and $\delta^{18} \mathrm{O}$ in monthly precipitation and in the Sava River and groundwaters from the Petruševec aquifer during 2010 
Table 2

$\delta^{18} \mathrm{O}$ mean values with standard deviation and the minimum and maximum $\delta^{18} \mathrm{O}$ values in the Sava River and groundwater of the Petruševec aquifer during 2010

\begin{tabular}{lccc}
\hline \multicolumn{1}{c}{ Location } & mean \pm & $\begin{array}{c}{ }^{18} \mathrm{O}(\%) \\
\text { minimum }\end{array}$ & maximum \\
\hline Sava River & $-9.5 \pm 0.4$ & -10.33 & -8.54 \\
Well B-5A & $-9.2 \pm 0.2$ & -9.48 & -8.96 \\
\hline Piezometer PP-23/5 & $-9.1 \pm 0.3$ & -9.59 & -8.74 \\
\hline Piezometer PP-18/30 & $-9.1 \pm 0.3$ & -9.57 & -8.71 \\
\hline Piezometer PP-19 & $-9.2 \pm 0.2$ & -9.47 & -8.94
\end{tabular}

$\delta^{2} \mathrm{H}$ vs. $\delta^{18} \mathrm{O}$ in the Sava River and all groundwaters laid above the LMWL for Zagreb precipitation from 2010 (Fig. 3) and was described as $\delta^{2} \mathrm{H}=(7.5 \pm 0.3)$ $\delta^{18} \mathrm{O}+(8.2 \pm 2.6), \mathrm{n}=47, \mathrm{R}=0.972$. This relation could be compared with the long-term (1981-2006) LMWL for precipitation in Ljubljana, Slovenia: $\delta^{2} \mathrm{H}=(8.1$ $\pm 0.1) \delta^{18} \mathrm{O}+(9.8 \pm 0.7), \mathrm{n}=290, \mathrm{R}=0.99$ (Vreca et al. 2008). Ljubljana is geographically much closer to the springs of the Sava River than Zagreb and

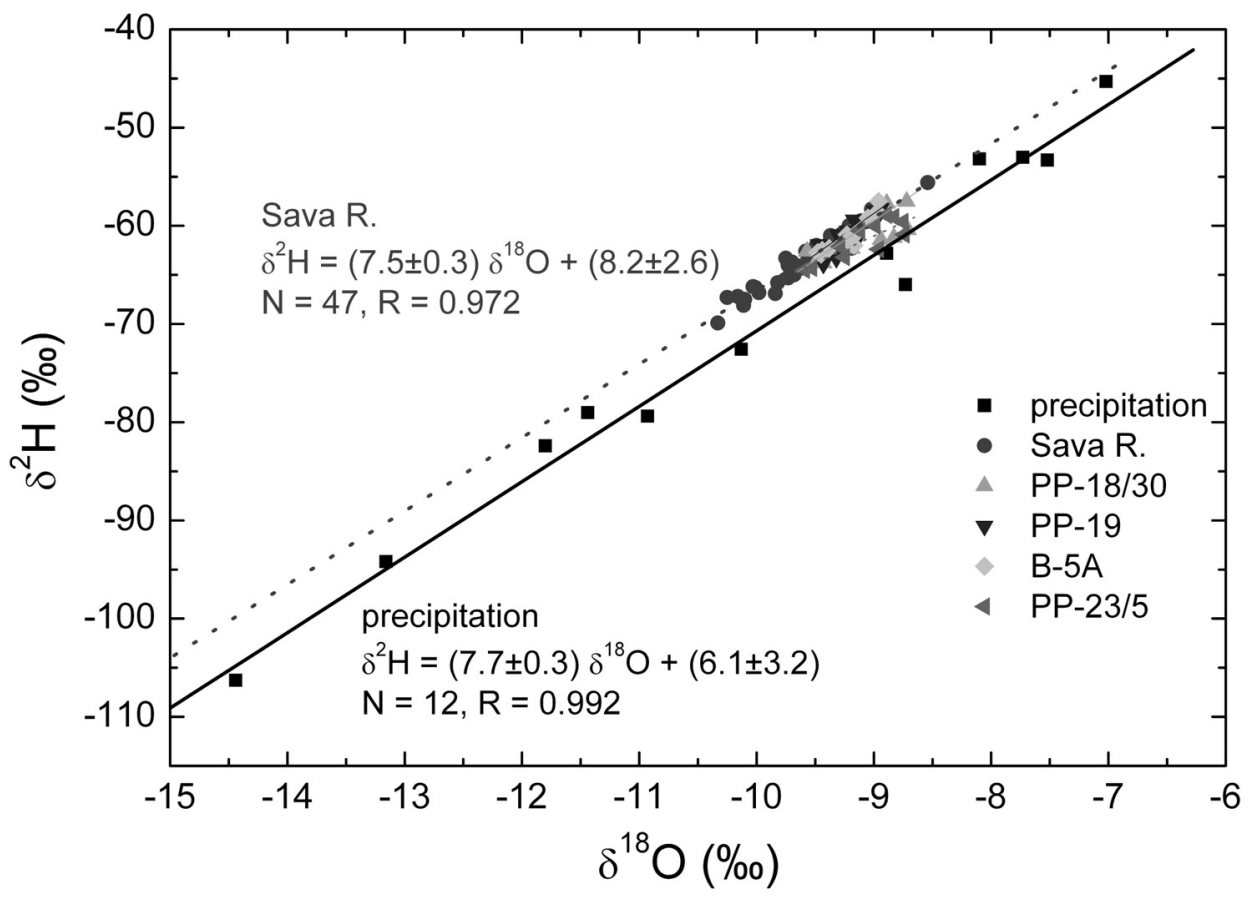

Fig. 3

Relation between $\delta^{18} \mathrm{O}$ and $\delta^{2} \mathrm{H}$ in the Sava River and in groundwaters of the Petruševec aquifer during 2010 
therefore the LMWL for Ljubljana precipitation better describes the stable isotopic composition of the Sava River recharge area. All groundwater values laid very close to the correlation line of the Sava River (Fig. 3) showing direct influence of the Sava River on the groundwater of the Petruševec aquifer. Differences in monthly variations of $\delta^{18} \mathrm{O}$ values between particular wells (Table 2), together with ${ }^{3} \mathrm{H}$ activities, indicated different infiltration times of surface water of the Sava River to different wells of the Petruševec aquifer: the wells B$5 \mathrm{~A}$ and PP-19, which showed the slowest response to the changes in ${ }^{3} \mathrm{H}$ in the Sava River, had also the smallest standard deviations and narrow range of the $\delta^{18} \mathrm{O}$ values.

\section{Conclusions}

Results of measurements of ${ }^{3} \mathrm{H}$ and stable isotopes ${ }^{2} \mathrm{H} /{ }^{1} \mathrm{H}$ and ${ }^{18} \mathrm{O} /{ }^{16} \mathrm{O}$ in precipitation, the Sava River and groundwaters from the Petruševec aquifer in the Zagreb area showed the following:

The isotopic water line ( $\delta^{2} \mathrm{H}$ vs. $\delta^{18} \mathrm{O}$ relation) of the Sava River was closer to the Local Meteoric Water Line for Ljubljana precipitation than that for Zagreb precipitation indicating the source of river water. The time series of stable isotope composition of groundwater followed that of the Sava River showing a direct influence of the river on the groundwater of the Petruševec aquifer.

Significantly higher ${ }^{3} \mathrm{H}$ activity of the Sava River in June 2010 indicated the influence of the release of tritiated water from the Nuclear Power Plant Krško. Maximal ${ }^{3} \mathrm{H}$ activity was detected $1-2$ days after the release.

Increase in ${ }^{3} \mathrm{H}$ activities in groundwater of the Petruševec aquifer was less pronounced and showed different time delay of 3 to 5 months for different wells. Intensity and time delay of the response could be correlated to the depth of the wells and the distance from the Sava River. This observation pointed to some differences in the infiltration time of the water from the Sava River to individual wells.

In this case ${ }^{3} \mathrm{H}$ has been proven to be a good environmental tracer for determination of the transit time of the river water to the aquifer. The results of ${ }^{3} \mathrm{H}$ and stable isotopes ${ }^{2} \mathrm{H} /{ }^{1} \mathrm{H}$ and ${ }^{18} \mathrm{O} /{ }^{16} \mathrm{O}$ will be used for modelling the transit time of the Sava River water to the groundwater reservoirs/aquifers.

\section{Acknowledgements}

We thank dipl.ing. Branka Jakuš, Mira Mihovec Grdic and Mladen Klemar, from water supply company "Vodoopskrba i odvodnja", Zagreb, for help in water sampling of aquifer Petruševec and for data about the aquifer. This work was performed as a part of the IAEA Project RER/8/016 and the Project 098-09827092741 from the Ministry of Science, Education and Sport. 


\section{References}

Barešič, J, N. Horvatinčić, I. Krajcar Broić, B. Obelić, J. Kozar-Logar 2011: Tritium activity measurement of water samples using liquid scintillation counter and electrolytical enrichment. - Proceedings of the 8th Symposium of Croatian Radiation Protection Association, Krk, Croatia, 13-15 April, 2011. HDZZ, Zagreb, 2011. pp. 461-467.

IAEA/WMO, 2011. Global Network of Isotopes in Precipitation. The GNIP database. Accessible at: http://isohis.iaea.org and http://nds121.iaea.org/wiser/index.php (9 May 2011)

Rozanski, K., R. Gonfiantini, L. Araguas-Araguas 1991: Tritium in the global atmosphere: distribution patterns and recent trends. - J Phys G: Nucl Part Phys 17, pp. 523-536.

Stepišnik, M. 2011: Sava. - In: Stepišnik, M., B. Zorko (Eds): Assessment of the influence of radioactivity in the environment of the Nuclear Power Plant Krško on the public. Jozef Stefan Institute, Ljubljana, Slovenia 2011, pp. 1-18. (In Slovene.)

Vreča, P., I. Krajcar Bronić, N. Horvatinčić, J. Barešić 2006: Isotopic characteristics of precipitation in Slovenia and Croatia: Comparison of continental and maritima stations. - J. Hydrology, 330, pp. $457-469$.

Vreča, P., I. Krajcar Bronić, A. Leis, M. Brencić 2008: Isotopic composition of precipitation in Ljubljana (Slovenia). - Geologija, (Ljubljana) 51/2, pp. 169-182. 